\title{
Article \\ Hydrogen-Rich Gas Production from Two-Stage Catalytic Pyrolysis of Pine Sawdust with Calcined Dolomite
}

\author{
Tao $\mathrm{Xu} * \mathbb{D}$, Jue $\mathrm{Xu}$ and Yongping $\mathrm{Wu}$
}

check for

updates

Citation: $\mathrm{Xu}, \mathrm{T}$; $\mathrm{Xu}, \mathrm{J} . ; \mathrm{Wu}, \mathrm{Y}$. Hydrogen-Rich Gas Production from Two-Stage Catalytic Pyrolysis of Pine Sawdust with Calcined Dolomite. Catalysts 2022, 12, 131. https:// doi.org/10.3390/catal12020131

Academic Editors: Baiqian Dai, Xiaojiang Wu and Lian Zhang

Received: 20 December 2021

Accepted: 20 January 2022

Published: 21 January 2022

Publisher's Note: MDPI stays neutral with regard to jurisdictional claims in published maps and institutional affiliations.

Copyright: (C) 2022 by the authors. Licensee MDPI, Basel, Switzerland. This article is an open access article distributed under the terms and conditions of the Creative Commons Attribution (CC BY) license (https:// creativecommons.org/licenses/by/ $4.0 /)$

\author{
School of Energy Engineering, Xi'an University of Science and Technology, Xi'an 710054, China; \\ juexxu@163.com (J.X.); wuyp@xust.edu.cn (Y.W.) \\ * Correspondence: xutao@xust.edu.cn
}

\begin{abstract}
The potential of catalytic pyrolysis of biomass for hydrogen and bio-oil production has drawn great attention due to the concern of clean energy utilization and decarbonization. In this paper, the catalytic pyrolysis of pine sawdust with calcined dolomite was carried out in a novel moving bed reactor with a two-stage screw feeder. The effects of pyrolysis temperature $\left(700-900{ }^{\circ} \mathrm{C}\right)$ and catalytic temperature $\left(500-800{ }^{\circ} \mathrm{C}\right)$ on pyrolysis performance were investigated in product distribution, gas composition, and gas properties. The results showed that with the temperature increased, pyrolysis gas yield increased, but the yield of solid and liquid products decreased. With the increase in temperature, the $\mathrm{CO}$ and $\mathrm{H}_{2}$ content increased significantly, while the $\mathrm{CO}_{2}$ and $\mathrm{CH}_{4}$ decreased correspondingly. The calcined dolomite can remove the tar by $44 \%$ and increased syngas yield by $52.9 \%$. With the increasing catalytic temperature, the catalytic effect of calcined dolomite was also enhanced.
\end{abstract}

Keywords: catalytic pyrolysis; biomass; hydrogen; two-stage; dolomite; temperature; catalytic temperature

\section{Introduction}

Biomass is a carbon-neutral renewable fuel with significant potential to reduce greenhouse gas emissions. China has abundant biomass reserves, with an annual production of about 3.494 billion tons, including available straw resources (694 million tons) and forestry residues (350 million tons). All of this showed great potential for energy utilization [1]. Biomass can be converted into a variety of high-value products, including chemicals, biofuels and advanced materials by thermochemical and biochemical pathways. Among different technologies of biomass utilization, thermochemical conversion is the most efficient method with the shortest time scale of the process [2]. Thermochemical conversion includes pyrolysis, hydrothermal liquefaction and gasification [3-5]. Pyrolysis is a promising technology for biofuels and chemicals and is considered a revolutionary and straightforward energy production method [6,7].

Pyrolysis is an efficient thermochemical conversion technology, which can accomplish the poly-generation of solid, liquid and gas products [8]. Pyrolysis is a process in which carbon-based raw materials such as biomass are heated and converted into char, $\operatorname{tar}, \mathrm{CO}, \mathrm{H}_{2}$, $\mathrm{CH}_{4}$ and other hydrocarbons under anoxic conditions. The pyrolysis of biomass is able to produce liquid fuels, hydrogen and high-value chemicals [9-11]. Pyrolysis can process all kinds of organic waste and efficiently transform them into energy, with significant economic and environmental benefits. Therefore, utilizing biomass pyrolysis for hydrogen-rich gas can not only reduce the pressure of energy and the environment but also accomplish resource utilization of agricultural and forestry wastes.

Some research on biomass pyrolysis has been carried out in the literature. Cho et al. evaluated the value of sesame waste pyrolysis for syngas, found that the increase in syngas yield was proportional to temperature $\left(500{ }^{\circ} \mathrm{C}, 600^{\circ} \mathrm{C}, 700{ }^{\circ} \mathrm{C}\right)$ [12]. Kazimierski et al. prepared biochar by pyrolysis of orchard pruning residue between $25^{\circ} \mathrm{C}$ and $600{ }^{\circ} \mathrm{C}$ and 
measured the pyrolysis products yield. The results showed that the high heating value of the pyrolysis products increased from $29.52 \mathrm{MJ} / \mathrm{kg}\left(400^{\circ} \mathrm{C}\right)$ to $30.53 \mathrm{MJ} / \mathrm{kg}\left(600{ }^{\circ} \mathrm{C}\right)$ [13]. Parket al. conducted pyrolysis of bark and studied the effect of temperature on the threephase pyrolysis products. The results showed that with the increase in temperature from $300{ }^{\circ} \mathrm{C}$ to $700{ }^{\circ} \mathrm{C}$, the non-condensable gas increased from $6.3 \mathrm{wt} \%$ to $17.5 \mathrm{wt} \%$, while char yield decreased from $63.6 \mathrm{wt} \%$ to $30.6 \mathrm{wt} \%$ [14]. Gao et al. and Desisto et al. investigated the influence of temperature on the pyrolysis of pine sawdust $[15,16]$. They found that the maximum liquid yield was achieved at $500{ }^{\circ} \mathrm{C}$ and gas yield increased with temperature. However, most studies on pyrolysis were limited to low or medium temperatures for liquid fuels, the high-temperature pyrolysis of biomass for hydrogen and syngas has been rarely studied.

Catalyst can significantly influence the biomass pyrolysis process, improving the product quality and reaction efficiency. The catalysts for biomass catalytic pyrolysis can be divided into synthetic metal catalysts and natural ore catalysts. Metal catalysts include alkali metal catalysts, iron-based catalysts, nickel-based catalysts and mixed metal catalysts. Xie et al. investigated the effect of pyrolysis temperature on gas production of pine sawdust using different nickel-based catalysts [17]. Their results indicated that more syngas and high-quality char could be obtained at $750{ }^{\circ} \mathrm{C}$. Qu et al. used Ni/Fe bimetal ZSM-5 as a catalyst to study the catalytic pyrolysis kinetics and product properties of waste tires. The results showed that ZSM-5loaded with $7 \mathrm{wt} \% \mathrm{Ni}$ and $3 \mathrm{wt} \%$ Fe had the best catalytic effect, and the catalytic activation energy decreased by 13\% [18]. Galiwango et al. used transition metal phosphatizing catalysts of nickel, cobalt and iron to catalyze the pyrolysis of jujube palm. The study found that the product yield of C7-C8 compounds was 3.6\% without catalyst and increased to $68.0 \%$ with a catalyst [19]. Kim et al. used soil-rich catalysts $\left(\mathrm{Co} / \mathrm{SiO}_{2}\right.$ and $\left.\mathrm{Ni} / \mathrm{SiO}_{2}\right)$ to pyrolyze two kinds of biomass (barn grass and echinococcus). Under the catalyst of $\mathrm{Ni}$ and $\mathrm{Co}$, the syngas yield was 2-3 times greater than that of catalyst-free pyrolysis [20]. Laura et al. and Gao et al. have recently reported the state-ofthe-art of metal catalysts, particularly in Ni-based catalysts, for biomass pyrolysis [21,22]. Although Ni-based catalysts such as $\mathrm{Ni} / \mathrm{Al}_{2} \mathrm{O}_{3}$ have been widely used and studied for reforming biomass tar, current studies are limited to bench scale. Further knowledge of the catalyst is required to scale up for industrial application, especially in catalyst deactivation and regeneration.

Compared with synthetic mental catalysts, natural ore catalysts are of low cost, including dolomite, magnesite, olivine, limestone and calcite. Aljeradat et al. studied the catalytic effect of different minerals on the jujube kernel pyrolysis. They found that the catalytic oil productions rate of oil shale ash was the highest (44\%), and the catalytic gas productions rate of zeolite tuff was the highest $(138.1 \mathrm{~mL} / \mathrm{g}$-feed) [23]. Khan et al. studied acid pretreatment and subsequent pyrolysis of rice straw in the presence of natural zeolite and HZSM-5 catalysts. The results showed that both catalysts significantly promoted the conversion of oxygen compounds to hydrocarbons [24]. Kawi et al. reviewed the research progress of biomass tar reforming catalyzed by natural minerals and waste. Dolomite had effective tar conversion performance, and olivine behaved similarly to dolomite. Both dolomite and calcite showed higher phenol conversion and selectivity at a higher temperature [25]. However, there are few studies on the catalytic pyrolysis of woody biomass using low-cost natural ore catalysts at high temperatures.

This study aims to study the high-temperature catalytic pyrolysis performance of pine sawdust for hydrogen-rich gas using calcined dolomite as a catalyst in a two-stage moving bed. The pyrolysis performance was examined in terms of pyrolysis products' distribution, gas composition, and gas properties. Firstly, the effects of pyrolysis temperature on pyrolysis performance were studied without catalysts. Moreover, the effect of catalytic temperature on pyrolysis performance was studied with calcined dolomite.

The majority of the catalytic pyrolysis studies in the literature are conducted using highcost metal catalysts, which resulted in difficulty for the large-scale application. However, this study used a low-cost modified natural ore catalyst, calcined dolomite, for the pyrolysis 
experiments. The influence of the high temperature $\left(700-900^{\circ} \mathrm{C}\right)$ and catalytic temperature $\left(500-800^{\circ} \mathrm{C}\right)$ was investigated by monitoring product distribution, gas composition, and gas properties.

\section{Results and Discussion}

\subsection{Effect of Temperature on Pyrolysis}

The pyrolysis experiments of pine sawdust were conducted at $700-900{ }^{\circ} \mathrm{C}$ in the pyrolysis bed without using catalysts in order to investigate the effect of temperature on pyrolysis performance. In the experiments, the velocity of the primary and secondary screw feeder was $171 \mathrm{r} / \mathrm{h}$ and $300 \mathrm{r} / \mathrm{h}$, respectively, and the feeding rate of the biomass was $36 \mathrm{~g} / \mathrm{min}$. The mass balance of the pyrolysis experiments was in the range of $92-96 \%$.

\subsubsection{Effect of Temperature on Pyrolysis Products' Distribution}

In flash pyrolysis, biomass generated three kinds of products in gas, liquid and solid. The gas and solid products were pyrolysis gas and the solid residue of biomass (char), respectively. The liquid product was tar generated during pyrolysis. The influence of temperature on the distribution of pine sawdust pyrolysis products is shown in Figure 1. With the pyrolysis temperature increasing, the gas yield increased, while the solid and liquid yield gradually decreased. Specifically, the gas yield increased from $50.67 \mathrm{wt} \%$ at $700{ }^{\circ} \mathrm{C}$ to $74.19 \mathrm{wt} \%$ at $900{ }^{\circ} \mathrm{C}$. However, solid and liquid yield fell by $12.98 \mathrm{wt} \%$ and $10.54 \mathrm{wt} \%$, respectively. In general, the high temperature was favorable to the formation of gaseous products, while the medium and low temperature was beneficial to the formation of liquid and solid products. The increase in gas products was because the growth of reaction temperature accelerated the primary pyrolysis of pine sawdust, and then promoted the secondary thermal cracking of the volatiles and char. The results were consistent with the research results of $\mathrm{Li}$ et al. [26] and $\mathrm{Xu}$ et al. [27]. Li et al. found that tar yield increased when the temperature rose, but it decreased after reaching a peak point (about $600{ }^{\circ} \mathrm{C}$ ) because of the secondary cracking reactions [26]. In particular, the increase in gas products at a high temperature of $800-900{ }^{\circ} \mathrm{C}$ was due to the tar cracking and thermal cracking of char, which also led to a reduction in liquid and solid yield.

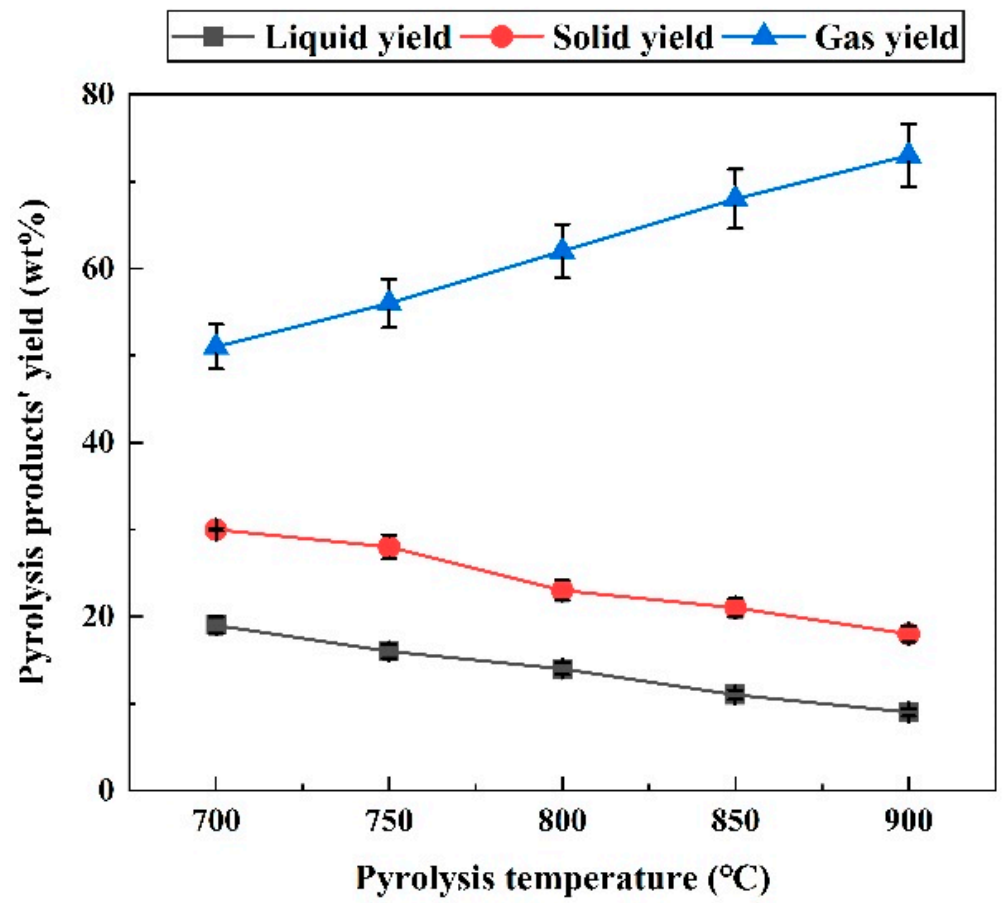

Figure 1. Effect of temperature on the distribution of pyrolysis products of pine sawdust. 


\subsubsection{Effect of Temperature on Gas Composition}

Figure 2 shows the influence of pyrolysis temperature on the composition of gas products from pine sawdust pyrolysis. The generated pyrolysis gas above $700{ }^{\circ} \mathrm{C}$ was mainly composed of $\mathrm{CO}, \mathrm{H}_{2}, \mathrm{CO}_{2}$ and $\mathrm{CH}_{4}$, which accounts for more than $94 \%$ of gas components. As shown in Figure 2, the $\mathrm{CO}$ content decreased as the temperature decreased during pyrolysis at $700-750{ }^{\circ} \mathrm{C}$. However, the $\mathrm{CO}$ content increased slightly during pyrolysis at $750-850{ }^{\circ} \mathrm{C}$ and then decreased rapidly from $40 \%$ to $33 \%$ between 850 and $900{ }^{\circ} \mathrm{C}$. At the same time, the $\mathrm{CO}_{2}$ content decreased by $15 \%$ at $700-900{ }^{\circ} \mathrm{C}$. This decrease in $\mathrm{CO}_{2}$ could be because of the improved Boudouard reaction (Equation (1)) between char and $\mathrm{CO}_{2}$ at high temperatures [28]. At $900{ }^{\circ} \mathrm{C}$, the $\mathrm{CO}_{2}$ and $\mathrm{CH}_{4}$ decreased, whereas the $\mathrm{H}_{2}$ increased, indicating the occurrence of the dry methane reforming reaction (Equation (3)). The decrease in $\mathrm{CO}$ at $900{ }^{\circ} \mathrm{C}$ may be a result of the reverse Boudouard reaction (Equation (2)) [29].

$$
\begin{array}{ll}
\mathrm{C}+\mathrm{CO}_{2} \rightarrow 2 \mathrm{CO} & \Delta \mathrm{H}_{298 \mathrm{~K}}=+159 \mathrm{~kJ} / \mathrm{mol} \quad \Delta \mathrm{G}_{1100 \mathrm{~K}}=-21.8 \mathrm{~kJ} / \mathrm{mol} \\
2 \mathrm{CO} \rightarrow \mathrm{C}+\mathrm{CO}_{2} & \Delta \mathrm{H}_{298 \mathrm{~K}}=-172 \mathrm{~kJ} / \mathrm{mol} \quad \Delta \mathrm{G}_{1173 \mathrm{~K}}=-162 \mathrm{~kJ} / \mathrm{mol} \\
\mathrm{CH}_{4}+\mathrm{CO}_{2} \rightarrow 2 \mathrm{CO}+2 \mathrm{H}_{2} & \Delta \mathrm{H}_{298 \mathrm{~K}}=+247 \mathrm{~kJ} / \mathrm{mol} \quad \Delta \mathrm{G}_{1173 \mathrm{~K}}=-17 \mathrm{~kJ} / \mathrm{mol}
\end{array}
$$

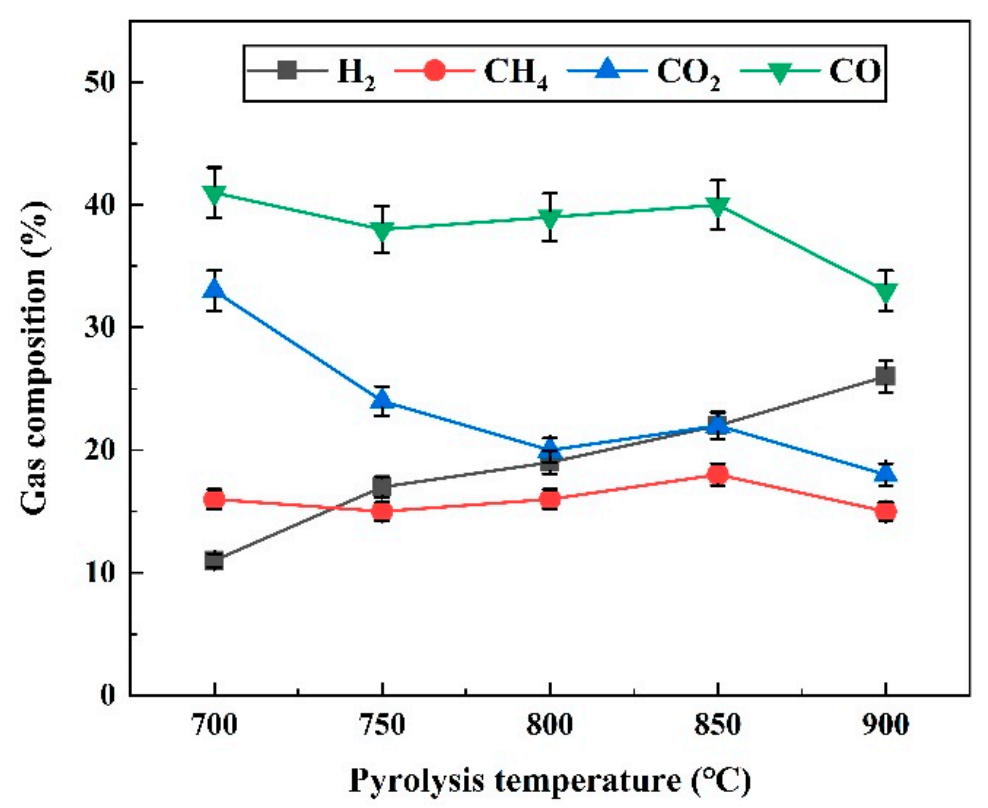

Figure 2. Effect of temperature on pyrolysis gas composition of pine sawdust.

The $\mathrm{CH}_{4}$ content was relatively stable and finally reduced by $1 \%$ with the increase in temperature. This was because the pine sawdust firstly happened gasification reaction with $\mathrm{O}_{2}$. When the $\mathrm{O}_{2}$ was exhausted, the remaining char gasified with $\mathrm{CO}_{2}$ and gas products continued the homogeneous reactions, as shown in Equations (1) and (2). Li et al. found that $\mathrm{CO}$ and $\mathrm{CO}_{2}$ were mainly from the $\mathrm{O}$-containing functional groups, including carboxyl and carbonyl. When pyrolysis temperature was higher than $200{ }^{\circ} \mathrm{C}$, carboxyl was broken to form $\mathrm{CO}_{2}$. When the temperature was higher than $400{ }^{\circ} \mathrm{C}$, carbonyl was split to form $\mathrm{CO}$ [26]. The concentration of $\mathrm{H}_{2}$ consistently increased with an increase in temperature, mainly due to the decomposition of tar and the secondary gas reaction. Similar results were observed in the study of Laura et al. [30] and Lin et al.'s [31], which also showed that the $\mathrm{H}_{2}$ content increased with an increase in pyrolysis temperature. The thermal decomposition of lignin and heavy hydrocarbons promoted $\mathrm{H}_{2}$ formation. Besides, the secondary reactions of bio-oil and self-gasification of pine sawdust also contributed to $\mathrm{H}_{2}$ formation as pyrolysis temperature increased [31]. 


\subsubsection{Effect of Temperature on Gas Products' Properties}

The influence of pyrolysis temperature on $\mathrm{H}_{2} / \mathrm{CO}$ and dry gas yield $\left(\mathrm{G}_{Y}\right)$ is shown in Figure 3. As seen, $\mathrm{H}_{2} / \mathrm{CO}$ ratio increased with the increase in pyrolysis temperature. In particular, the $\mathrm{H}_{2} / \mathrm{CO}$ ratio was 0.25 at $700{ }^{\circ} \mathrm{C}$, but at $900{ }^{\circ} \mathrm{C}$, it jumped to 0.77 , mainly because of the constant increase in $\mathrm{H}_{2}$ content. The rise of $\mathrm{H}_{2}$ was caused by the growth of pyrolysis temperature, which resulted in more $\mathrm{H}_{2}$ released from pine sawdust primary pyrolysis, tar cracking and gas conversion reactions. Similarly, the dry gas yield increased with an increase in pyrolysis temperature, but the increase rate of its value varied greatly over different temperature ranges. The growth rate of dry gas yield $700-800{ }^{\circ} \mathrm{C}$ was lower than that in the high-temperature range $\left(800-900{ }^{\circ} \mathrm{C}\right)$. At $900{ }^{\circ} \mathrm{C}, \mathrm{H}_{2} / \mathrm{CO}$ and the dry gas yield reached maximum values $\left(0.77\right.$ and $1.00 \mathrm{Nm}^{3} / \mathrm{kg}$ ). The increase in $\mathrm{H}_{2} / \mathrm{CO}$ was due to more $\mathrm{H}_{2}$ released from tar cracking and the secondary gas reaction compared to $\mathrm{CO}$. The increase in dry gas yield was because of the decomposition of semi-cellulose and cellulose with the temperature rise. Moreover, the lignin began to decompose at a higher temperature above $800^{\circ} \mathrm{C}$. In addition, with the temperature increasing, the secondary gas reaction also occurred, which reduced tar and char yield and increased dry gas yield.

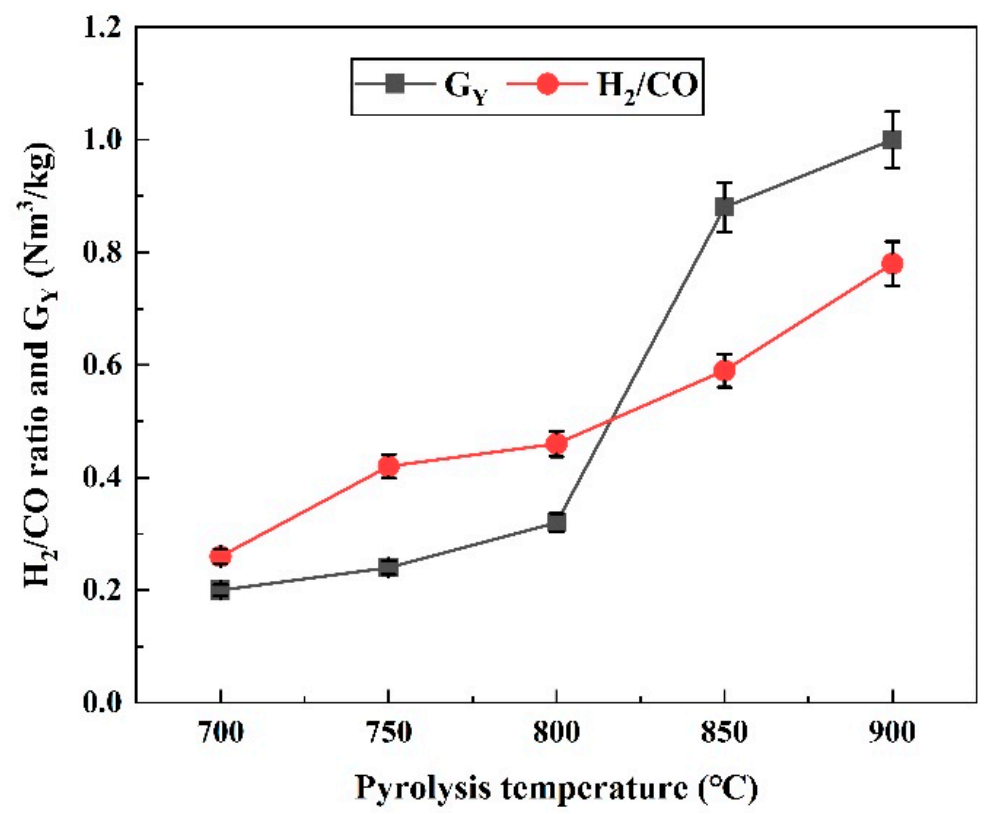

Figure 3. Effect of pyrolysis temperature on $\mathrm{H}_{2} / \mathrm{CO}$ and dry gas yield $\left(\mathrm{G}_{Y}\right)$ of pine sawdust.

\subsection{Catalytic Effect of Calcined Dolomite}

In this section, a pyrolysis bed was performed at $800{ }^{\circ} \mathrm{C}$, and calcined dolomite was used as the catalyst for the catalytic bed. The catalytic bed was conducted at $500-800{ }^{\circ} \mathrm{C}$ under $0.4 \mathrm{~h}^{-1}$ weight hourly space velocity to study the catalytic effect of calcined dolomite. The mass balance of the catalytic pyrolysis experiments was in the range of $91-97 \%$.

\subsubsection{Effect of Catalyst on Pyrolysis Products Yield}

Figure 4 shows the catalytic effect of calcined dolomite on pyrolysis products of pine sawdust at different temperatures. The change in char yield was small with or without catalyst, ranging from 11.49 to $11.67 \mathrm{wt} \%$. This was because the catalytic reforming bed only affected pyrolysis gas and tar, and it had no direct impact on char in the two-stage catalytic pyrolysis reactor. In the absence of the catalyst, the pyrolysis tar yield was $10.35 \mathrm{wt} \%$ at $800{ }^{\circ} \mathrm{C}$, but it decreased to $9.38 \mathrm{wt} \%$ after catalytic pyrolysis at $500{ }^{\circ} \mathrm{C}$. With the catalytic temperature increased to $800{ }^{\circ} \mathrm{C}$, the tar yield rapidly decreased to $3.83 \mathrm{wt} \%$. The experimental results showed that the tar yield decreased with the increasing catalytic temperature, and the removal rate of tar reached more than $60 \%$ under the catalysis of calcined dolomite at $800^{\circ} \mathrm{C}$. 


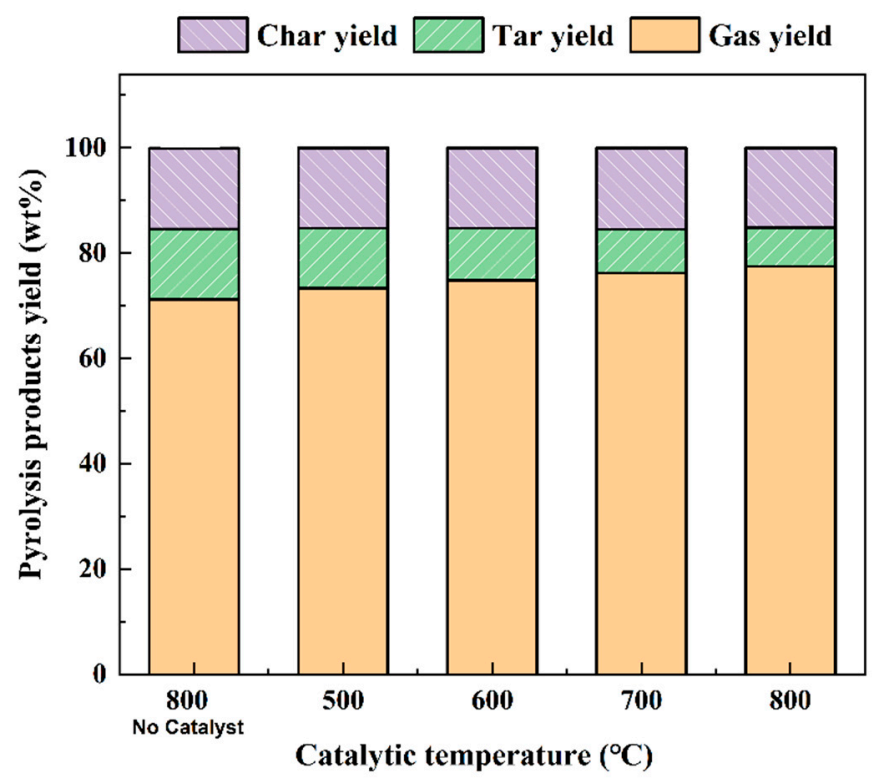

Figure 4. Effect of catalytic temperature on the distribution of pyrolysis products of pine sawdust.

The trend of gas yield was just the opposite. With the increase in tar yield, gas yield increased significantly. The gas yield of pine sawdust was $61.23 \mathrm{wt} \%$ under catalyst-free pyrolysis at $800^{\circ} \mathrm{C}$. However, when the pyrolysis gas entered the catalytic reforming bed, the gas yield increased significantly. With the increase in catalytic temperature from $500{ }^{\circ} \mathrm{C}$ to $800{ }^{\circ} \mathrm{C}$, the catalytic pyrolysis gas yield increased from $68.34 \mathrm{wt} \%$ to $78.12 \mathrm{wt} \%$. The increase in gas yield was mainly attributed to the catalyst, which promoted the cracking of tar and organic volatiles. Since the pyrolysis of pine sawdust was mainly carried out in the pyrolysis bed, the role of catalyst in the catalytic reforming bed was to catalyze the pyrolysis of tar, thus increasing the yield of gas products.

\subsubsection{Effect of Catalyst on Gas Composition}

The composition of pyrolysis gas of pine sawdust at different catalytic temperatures is shown in Figure 5. The main gas components were $\mathrm{H}_{2}, \mathrm{CO}, \mathrm{CH}_{4}$ and $\mathrm{CO}_{2}$, while $\mathrm{N}_{2}$ and $\mathrm{O}_{2}$ were absent. Without the catalyst, $\mathrm{CO}$ and $\mathrm{CO}_{2}$ were the main gas components. However, in the presence of the catalyst, the $\mathrm{H}_{2}$ and $\mathrm{CO}$ contents increased significantly. With the increase in catalytic temperature from $500{ }^{\circ} \mathrm{C}$ to $800{ }^{\circ} \mathrm{C}$, the $\mathrm{H}_{2}$ and $\mathrm{CO}$ contents rose by $9.43 \mathrm{vol} \%$ and $11.45 \mathrm{vol} \%$. The increase in $\mathrm{H}_{2}$ and $\mathrm{CO}$ contents was attributed to the release of $\mathrm{H}_{2}$ and $\mathrm{CO}$ from the tar cracking. The catalyst also promoted secondary gas reactions such as water-gas reactions (Equation (4)) and methane reforming reactions (Equation (3)). At the same time, the whole process was endothermic, so the increasing temperature was conducive to the catalytic cracking of tar. The research results of Zhao et al. showed that the increasing temperature promoted the dry methane reforming reaction between $\mathrm{CO}_{2}$ and $\mathrm{CH}_{4}$ (Equation (4)), leading to an increase in the $\mathrm{H}_{2}$ and $\mathrm{CO}$ content [32].

$$
\mathrm{CO}+\mathrm{H}_{2} \mathrm{O} \rightarrow \mathrm{CO}_{2}+\mathrm{H}_{2} \quad \Delta \mathrm{H}_{298 \mathrm{~K}}=-40 \mathrm{~kJ} / \mathrm{mol} \quad \Delta \mathrm{G}_{1173 \mathrm{~K}}=-11 \mathrm{~kJ} / \mathrm{mol}
$$

On the contrary, the $\mathrm{CO}_{2}$ content decreased significantly in the presence of the catalyst. The $\mathrm{CO}_{2}$ content decreased from $34.33 \%$ to $27.88 \%$ at $500{ }^{\circ} \mathrm{C}$, and the $\mathrm{CO}_{2}$ content continued to decline with the increase in catalytic temperature. When it reached $800{ }^{\circ} \mathrm{C}$, the content was only $17.53 \%$. This was because the active components of calcined dolomite were $\mathrm{MgO}$ and $\mathrm{CaO}$, which absorbed $\mathrm{CO}_{2}$ in the reaction. Similarly, the $\mathrm{CH}_{4}$ content decreased considerably with the increase in catalytic temperature. This was because calcined dolomite catalyzed the tar cracking and secondary gas reaction. The experimental results showed that calcined dolomite could effectively promote the cracking of tar and secondary gas reaction, so the $\mathrm{H}_{2}$ and $\mathrm{CO}$ contents significantly increased. 


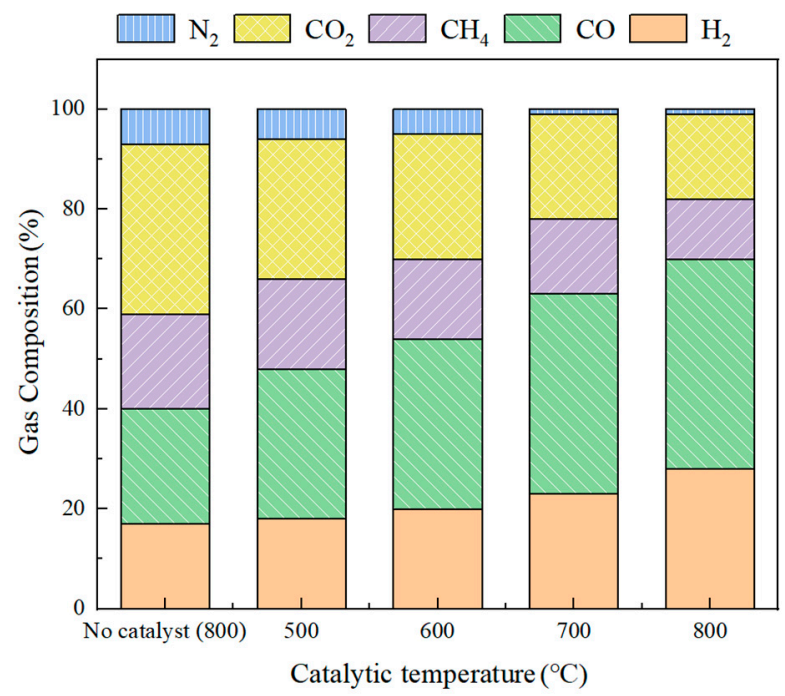

Figure 5. Effect of catalytic temperature on pyrolysis gas composition of pine sawdust.

\subsubsection{Effect of Catalyst on Gas Products' Properties}

The effect of catalytic temperature on the properties of pyrolysis gas products is presented in Table 1. As can be seen from Table 1 , the syngas $\left(\mathrm{H}_{2}+\mathrm{CO}\right)$ content increased significantly after catalytic pyrolysis, from $45.48 \%$ (catalyst-free pyrolysis) to $48.71 \%$ (catalytic pyrolysis at $500{ }^{\circ} \mathrm{C}$ ). The syngas content increased steadily to $69.55 \%$ when the catalytic temperature increased to $800{ }^{\circ} \mathrm{C}$. This was due to the increasing trend of $\mathrm{CO}$ and $\mathrm{H}_{2}$ content at higher catalytic temperatures. Similarly, the $\mathrm{H}_{2} / \mathrm{CO}$ ratio was only 0.47 before the catalytic pyrolysis. After catalysis at $500{ }^{\circ} \mathrm{C}$, the $\mathrm{H}_{2} / \mathrm{CO}$ ratio rose to 0.58 and constantly increased with the increase in catalytic temperature, reaching a maximum of 0.65 at $800{ }^{\circ} \mathrm{C}$. This was due to the fact that the tar cracking and secondary gas reaction released $\mathrm{more}_{2}$ than $\mathrm{CO}$ with the increasing temperature.

Table 1. Effect of catalytic temperature on properties of gas products.

\begin{tabular}{cccccc}
\hline Catalytic Temperature $\left({ }^{\circ} \mathbf{C}\right)$ & No Catalyst (800) & $\mathbf{5 0 0}$ & $\mathbf{6 0 0}$ & $\mathbf{7 0 0}$ & $\mathbf{8 0 0}$ \\
\hline $\mathrm{H}_{2} / \mathrm{CO}(-)$ & 0.47 & 0.58 & 0.59 & 0.60 & 0.65 \\
Syngas $\left(\mathrm{H}_{2}+\mathrm{CO}\right)(\%)$ & 45.48 & 48.71 & 55.09 & 67.04 & 69.55 \\
Dry gas yield $\left(\mathrm{Nm}^{3} / \mathrm{kg}\right)$ & 0.36 & 0.41 & 0.47 & 0.48 & 0.74 \\
Carbon conversion $(\mathrm{wt} \%)$ & 34.23 & 36.72 & 41.11 & 44.62 & 61.43 \\
$\mathrm{LHV}\left(\mathrm{MJ} / \mathrm{Nm}^{3}\right)$ & 12.4 & 12.13 & 12.50 & 13.75 & 12.72 \\
\hline
\end{tabular}

The dry gas yield also increased significantly with a catalyst. Under the condition of no catalyst, the dry gas yield was only $0.36 \mathrm{Nm}^{3} / \mathrm{kg}$. After catalysis at $500{ }^{\circ} \mathrm{C}$, the dry gas yield increased from $0.41 \mathrm{Nm}^{3} / \mathrm{kg}$ to $0.74 \mathrm{Nm}^{3} / \mathrm{kg}$. The increase in dry gas yield can be attributed to the catalytic cracking of the tar. In addition, the value of carbon conversion increased with the increase in catalytic temperature. The experimental results showed that calcined dolomite could effectively increase the syngas yield and improve the quality of syngas by increasing the ratio of $\mathrm{H}_{2}$ and $\mathrm{CO}$.

\section{Experimental Section}

\subsection{Sample Preparation}

The feedstock used in the experiment was pine sawdust, which came from the furniture processing factory of Wuhan in China. It was mainly sawdust, including shavings and wood residues from the wood processing. The sawdust was air-dried and screened by a vibrating material screener, and it was sieved to the particle sizes of more than 100 mesh (less than $177 \mu \mathrm{m}$ ). In addition, the raw materials were dried at $105^{\circ} \mathrm{C}$ for four hours in an oven before the experiments. The proximate analysis of the pine sawdust was measured 
according to the Chinese standard-GB/T 28731-2012. Ultimate analysis of the sample was carried out by an elemental analyzer (Vario Micro Cube, Elementar, Langenselbold, Germany). The results of proximate analysis and ultimate analysis of pine sawdust are shown in Table 2.

Table 2. The properties of pine sawdust (air-dry basis).

\begin{tabular}{|c|c|c|c|c|c|c|c|c|c|}
\hline \multirow{2}{*}{ Sample } & \multicolumn{4}{|c|}{ Proximate Analysis (wt\%) } & \multicolumn{5}{|c|}{ Ultimate Analysis (wt\%) } \\
\hline & Moisture & Volatile & Fixed Carbon & Ash & $\mathrm{C}$ & $\mathbf{H}$ & $\mathbf{N}$ & $S$ & O * \\
\hline Pine Sawdust & 9.18 & 62.23 & 15.77 & 11.82 & 46.36 & 5.75 & 2.26 & 0.35 & 47.28 \\
\hline
\end{tabular}

\subsection{Catalyst Preparation}

In this study, the low-cost natural ore was used as the catalyst. The main composition of the dolomite is $\mathrm{CaCO}_{3}$ and $\mathrm{MgCO}_{3}$, and it also contains a small amount of $\mathrm{Si}$, $\mathrm{Fe}$ and $\mathrm{Al}$, as well as some trace mineral impurity. The dolomite was calcined at $900{ }^{\circ} \mathrm{C}$ for $4 \mathrm{~h}$ in a muffle furnace and then crushed and sieved to a particle size of 3-10 $\mathrm{mm}$ was selected as the catalyst. Their XRD patterns are shown in Figure 6, and their surface characteristics are listed in Table 3. As shown in Figure 6, at $900{ }^{\circ} \mathrm{C}$, more $\mathrm{CaO}$ and $\mathrm{MgO}$ were generated by the decomposition of $\mathrm{CaMg}\left(\mathrm{CO}_{3}\right)_{2}$ in dolomite, and the catalytic components increased significantly after high-temperature calcination. As seen in Table 3, the specific surface area of calcined dolomite increased more than 30 times, compared to the original dolomite. Therefore, the catalytic properties of calcined dolomite were improved compared with the original dolomite. The chemical analysis of calcined dolomite is shown in Table 4. As seen, the $\mathrm{CaO}$ and $\mathrm{MgO}$ were the major components in calcined dolomite.

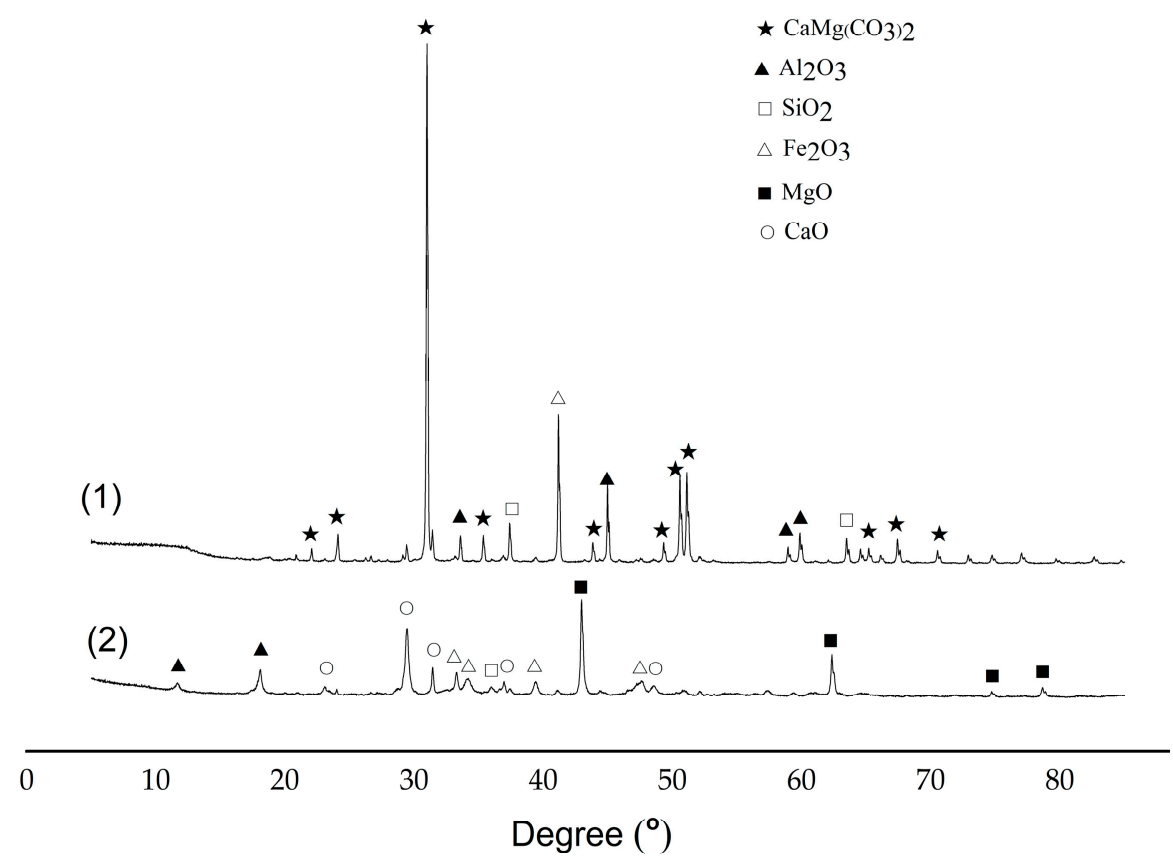

Figure 6. XRD patterns of dolomite (1) and calcined dolomite (2).

Table 3. The surface characterization of dolomite and calcined dolomite.

\begin{tabular}{ccccc}
\hline Samples & BET Surface Area $\left(\mathrm{m}^{2} / \mathrm{g}\right)$ & Micropore Surface Area $\left(\mathrm{m}^{2} / \mathrm{g}\right)$ & External Surface Area $\left(\mathrm{m}^{2} / \mathrm{g}\right)$ & Pore Volume $\left(\mathrm{cm}^{2} / \mathrm{g}\right)$ \\
\hline Dolomite & 0.32 & 0.14 & 0.31 & 0.07 \\
Calcined dolomite & 9.97 & 1.75 & 8.24 & 2.28 \\
\hline
\end{tabular}


Table 4. Chemical analysis of calcined dolomite (wt $\%)$.

\begin{tabular}{ccccccc}
\hline Catalyst & $\mathbf{C a O}$ & $\mathbf{M g O}$ & $\mathrm{SiO}_{\mathbf{2}}$ & $\mathrm{Fe}_{\mathbf{2}} \mathbf{O}_{3}$ & $\mathbf{A l}_{\mathbf{2}} \mathbf{O}_{\mathbf{3}}$ & $\mathbf{N a}_{\mathbf{2}} \mathbf{O}$ \\
\hline Calcined dolomite & 53.2 & 38.7 & 2.97 & 0.71 & 0.83 & 0.76 \\
\hline
\end{tabular}

\subsection{Experimental Apparatus and Procedures}

A self-designed two-stage catalytic pyrolysis reactor was used for catalytic pyrolysis experiments in our study. It was mainly composed of a two-stage screw feeder, a horizontal electric furnace, a temperature control system, a two-stage catalytic pyrolysis reactor (pyrolysis bed and catalytic reforming bed), and a gas cleaning and tar collecting system. The schematic diagram of the apparatus is shown in Figure 7.

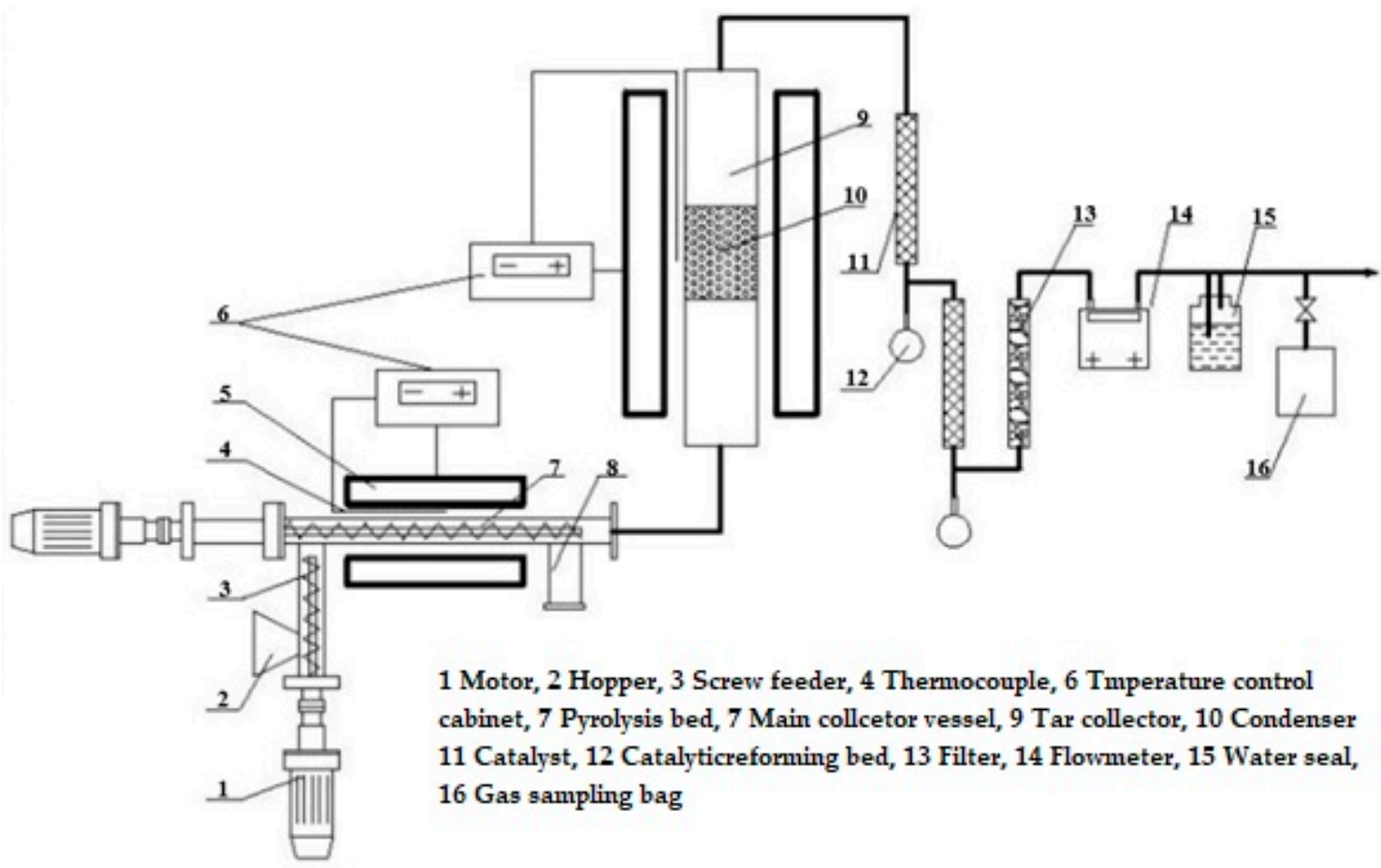

Figure 7. Schematic diagram of the two-stage catalytic pyrolysis reactor.

The two-stage screw feeder system consisted of two screw feeders. The screw feeder mainly included the screw, motor and hopper. The motor drove the rotation of the screw and then pushed the raw material forward. The primary screw feeder contained a hopper, and its end was connected with the pyrolysis reactor. A short distance was maintained between the screw end and the outlet of the feeder, to achieve a good sealing performance by forming a material seal. According to the cold mode tests, the input mass of the feeder was determined by the speed of the primary screw feeder. The secondary screw feeder was located in the pyrolysis reactor, and its rotational speed determined the biomass moving velocity within the reactor. The relationship between biomass moving velocity and the speed of the secondary screw feeder was measured by the cold mode experiment, which is shown in Figure 8.

The electric horizontal pyrolysis bed reactor with electric heating was used in this study. The horizontal pyrolysis bed reactor mainly consisted of a motor, screw feeder and ash hopper. The reactor was made of high-temperature-resistant stainless steel. The highest temperature of the reactor can reach up to $1000{ }^{\circ} \mathrm{C}$, the size of the internal reaction tube was $\varphi 80 \times 1100 \mathrm{~mm}$. The motor drove the rotation of the screw so that the biomass samples from the primary screw feeder moved forward and reacted in the pyrolysis reactor. Finally, the solid residue generated by the pyrolysis reactions fell into the ash hopper. An electric vertical tube reactor was used as the catalytic reforming bed. The reactor was made of high temperature resistant stainless steel material, with the designed highest temperature of 
$1000^{\circ} \mathrm{C}$, with an internal size of $\varphi 60 \times 1100 \mathrm{~mm}$. It was filled with the catalyst inside and had a gas outlet on the top.

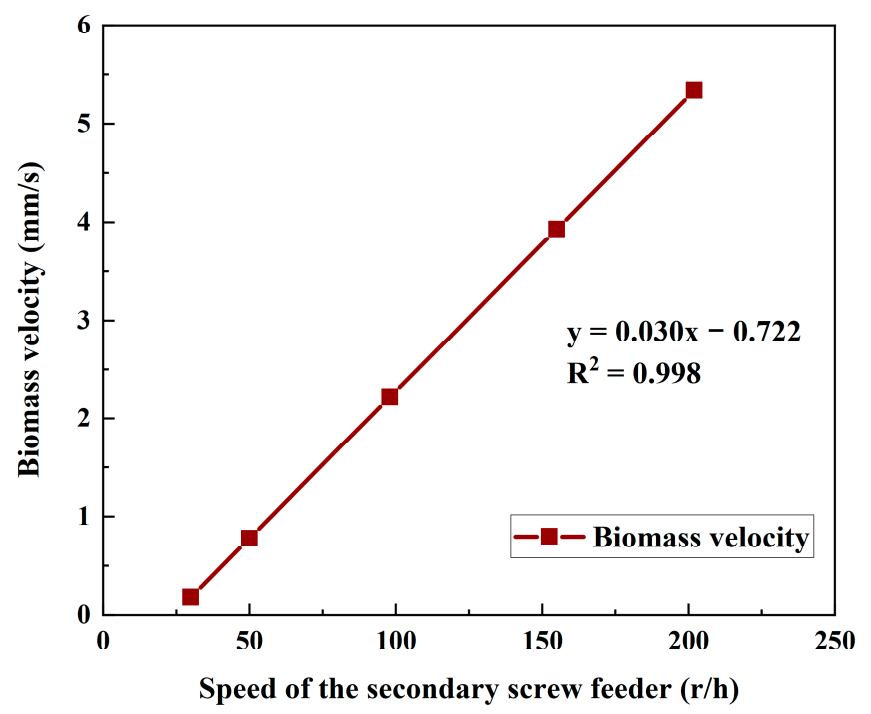

Figure 8. The relationship between biomass velocity and speed of the secondary screw feeder.

In the catalytic pyrolysis experiments, the pyrolysis bed and catalytic reforming bed were preheated, and around $300 \mathrm{~g}$ pine sawdust was set in the hopper. When the two reactors were heated to the required temperature, $\mathrm{N}_{2}$ was introduced for approximately half an hour to drain the oxygen from the system. After that, the two-stage screw feeder started feeding, under the primary feeding speed of $171 \mathrm{r} / \mathrm{h}$ and the secondary feeding speed of $300 \mathrm{r} / \mathrm{h}$. The pyrolysis reactions of the pine sawdust took place in the pyrolysis bed at $700-900{ }^{\circ} \mathrm{C}$. Then, the pyrolysis gas was inputted to the catalytic reforming reactor through the pipeline, and further cracked and reformed under the action of the catalyst. In the downstream, when the reformed gas passed the condensers under the ice water $\left(\sim 0{ }^{\circ} \mathrm{C}\right)$, most of the tar was condensed and collected by the collection impingers. The residual tar and impurities were absorbed and removed by the filters with the quartz cotton. The output gas flow rate was recorded by the gas flowmeter. Finally, the gas passed through the water-sealed bottle and was then ignited and exhausted.

After the experiment ran around 15 min under a steady-state, the generated gas was collected by a gas sampling bag and analyzed by gas chromatography (GC 9800 T, Kechuang, Shanghai, China). The gas yield was counted by the gas flowmeter. After the experiment, the collected tar from the collection bottles was weighted. Solid residues were collected from the ash hopper for weighing and analysis. Each experiment was repeated three times, and the results were averaged and presented.

\subsection{Data Analysis}

1. Dry gas yield, $\mathrm{G}_{Y}\left(\mathrm{Nm}^{3} / \mathrm{kg}\right)$, refers to the volume of gas that can be generated per kilogram of dried biomass, which was calculated by the following equation:

$$
\mathrm{G}_{\mathrm{Y}}=\text { Produced gas volume }\left(\mathrm{Nm}^{3}\right) \div \text { Dry biomass weight }(\mathrm{kg})
$$

2. Carbon conversion rate, $\eta_{c}(\%)$, refers to the ratio of carbon content in gas products to the carbon content in biomass, which was calculated by the following equation:

$$
\eta_{\mathrm{c}}=\frac{\mathrm{CO}+\mathrm{CO}_{2}+\mathrm{CH}_{4}+2 \times \mathrm{C}_{\mathrm{n}} \mathrm{H}_{\mathrm{m}}}{22.4 \times \mathrm{C}} \times 12 \mathrm{G}_{\mathrm{Y}} \times 100 \%
$$

where $C$ means the mass percentage of carbon in the ultimate analysis of samples, $\mathrm{G}_{\mathrm{Y}}$ is the dry gas yield, $\mathrm{CO}, \mathrm{CO}_{2}, \mathrm{CH}_{4}, \mathrm{C}_{\mathrm{n}} \mathrm{H}_{\mathrm{m}}$ are the volume ratio of $\mathrm{CO}, \mathrm{CO}_{2}, \mathrm{CH}_{4}$ and hydrocarbons in gas products. 
3. The low heating value of gas products $\left(\mathrm{LHV}, \mathrm{kJ} / \mathrm{Nm}^{3}\right)$ was calculated by the following equation:

$$
\mathrm{LHV}=\left(\mathrm{CO} \times 30.0+\mathrm{H}_{2} \times 25.7+\mathrm{CH}_{4} \times 85.4+\mathrm{C}_{\mathrm{n}} \mathrm{H}_{\mathrm{m}} \times 151.3\right) \times 4.2
$$

where $\mathrm{CO}, \mathrm{H}_{2}, \mathrm{CH}_{4}$ and $\mathrm{C}_{\mathrm{n}} \mathrm{H}_{\mathrm{m}}$, respectively, are their corresponding gas composition by volume in gas products.

\section{Conclusions}

In a two-stage catalytic pyrolysis reactor, the effects of pyrolysis temperature and catalytic temperature on catalytic pyrolysis performance of pine sawdust with calcined dolomite were studied. The main conclusions were summarized as follows:

1. High pyrolysis temperature improved gas yield by thermal cracking of solid and liquid products.

2. The $\mathrm{CO}, \mathrm{CH}_{4}$ and $\mathrm{CO}_{2}$ contents in gas decreased with the increase in temperature. $\mathrm{H}_{2} / \mathrm{CO}$, dry gas yield and carbon conversion rates all increased with the growth in temperature. The heating value of gas products reached a maximum value of $13.43 \mathrm{MJ} / \mathrm{Nm}^{3}$ at $850{ }^{\circ} \mathrm{C}$.

3. Calcined dolomite had good catalytic activity for biomass pyrolysis, which could increase the tar removing capability and syngas yield by $44.64 \%$ and by $52.92 \%$, respectively.

4. The increasing catalytic temperature could increase $\mathrm{H}_{2}$ and $\mathrm{CO}$ content in pyrolysis gas. In addition, increasing catalytic temperature also significantly improved $\mathrm{H}_{2} / \mathrm{CO}$ ratio, dry gas yield, carbon conversion and heating value.

However, the deactivation of the catalyst during the pyrolysis was not examined in this study, which will be further investigated in future work. Moreover, the number of catalysts used in this study was insufficient. Further investigation should be undertaken using more other natural ores catalysts for the optimum catalytic pyrolysis performance.

Author Contributions: Investigation, study design, data collection, data analysis, data interpretation, writing, T.X.; figures, data interpretation, literature search, writing, J.X.; funding acquisition, data interpretation, writing, Y.W. All authors have read and agreed to the published version of the manuscript.

Funding: National Natural Science Foundation of China (Grant No. 51634007), The Key Scientific and Technological Innovation Program of Shandong (Grant No. 2019JZZY020326), and Natural Science Basic Research Program of Shaanxi (Program NO. 2021JLM-10).

Acknowledgments: This study is supported by the Xi'an University of Science and Technology.

Conflicts of Interest: The authors declare no conflict of interest.

\section{References}

1. Zeng, Z.Q.; Tang, H.; Hu, Q.; Wang, S.L.; Li, M.H.; Yang, R.; Niu, Y.D.; Zhang, C.M. Tree biomass distribution patterns with a forest succession in subtropical China. Agron. J. 2021, 113, 706-710. [CrossRef]

2. Fatehi, H.; Weng, W.B.; Li, Z.S.; Bai, X.S.; Alden, M. Recent Development in Numerical Simulations and Experimental Studies of Biomass Thermochemical Conversion. Energy Fuels 2021, 35, 6940-6963. [CrossRef]

3. Zuorro, A.; Garcia-Martinez, J.B.; Barajas-Solano, A.F. The Application of Catalytic Processes on the Production of Algae-Based Biofuels: A Review. Catalysts 2021, 11, 22. [CrossRef]

4. $\mathrm{Xu}, \mathrm{T}$.; $\mathrm{Wu}, \mathrm{Y}$; B Bhattacharya, S. Gasification kinetic modelling of Victorian brown coal chars and validity for entrained flow gasification in $\mathrm{CO}_{2}$. Int. J. Min. Sci. Technol. 2021, 31, 473-481. [CrossRef]

5. $\mathrm{Xu}, \mathrm{T}$.; Bhattacharya, S. Direct and two-step gasification behaviour of Victorian brown coals in an entrained flow reactor. Energy Convers. Manag. 2019, 195, 1044-1055. [CrossRef]

6. Muhammad, I.; Manos, G. Improving the Conversion of Biomass in Catalytic Pyrolysis via Intensification of Biomass-Catalyst Contact by Co-Pressing. Catalysts 2021, 11, 805. [CrossRef]

7. Hasan, M.M.; Rasul, M.G.; Khan, M.M.K.; Ashwath, N.; Jahirul, M.I. Energy recovery from municipal solid waste using pyrolysis technology: A review on current status and developments. Renew. Sustain Energ. Rev. 2021, 145, 145. [CrossRef] 
8. Xu, T.; Srivatsa, S.C.; Bhattacharya, S. In-situ synchrotron IR study on surface functional group evolution of Victorian and Thailand low-rank coals during pyrolysis. J. Anal. Appl. Pyrolysis 2016, 122, 122-130. [CrossRef]

9. Suresh, A.; Alagusundaram, A.; Kumar, P.S.; Vo, D.V.N.; Christopher, F.C.; Balaji, B.; Viswanathan, V.; Sankar, S. Microwave pyrolysis of coal, biomass and plastic waste: A review. Environ. Chem. Lett. 2021, 19, 3609-3629. [CrossRef]

10. $\mathrm{Hu}, \mathrm{X}$.; Gholizadeh, M. Biomass pyrolysis: A review of the process development and challenges from initial researches up to the commercialisation stage. J. Energy Chem. 2019, 39, 109-143. [CrossRef]

11. Trninic, M.; Jovovic, A.; Stojiljkovic, D. A steady state model of agricultural waste pyrolysis: A mini review. Waste Manag. Res. 2016, 34, 851-865. [CrossRef] [PubMed]

12. Cho, S.H.; Cho, E.B.; Lee, J.H.; Moon, D.H.; Jung, S.; Kwon, E.E. Synergistic benefits for hydrogen production through $\mathrm{CO}_{2}-$ cofeeding catalytic pyrolysis of cellulosic biomass waste. Cellulose 2021, 28, 4781-4792. [CrossRef]

13. Kazimierski, P.; Hercel, P.; Suchocki, T.; Smoliński, J.; Pladzyk, A.; Kardaś, D.; Łuczak, J.; Januszewicz, K. Pyrolysis of Pruning Residues from Various Types of Orchards and Pretreatment for Energetic Use of Biochar. Materials 2021, 14, 2969. [CrossRef] [PubMed]

14. Park, C.; Lee, N.; Kim, J.; Lee, J. Co-pyrolysis of food waste and wood bark to produce hydrogen with minimizing pollutant emissions. Environ. Pollut. 2021, 270, 270. [CrossRef] [PubMed]

15. Ningbo, G.; Baoling, L.; Aimin, L.; Juanjuan, L. Continuous pyrolysis of pine sawdust at different pyrolysis temperatures and solid residence times. J. Anal. Appl. Pyrolysis 2015, 114, 155-162. [CrossRef]

16. DeSisto, W.J.; Hill, N.; Beis, S.H.; Mukkamala, S.; Joseph, J.; Baker, C.; Ong, T.-H.; Stemmler, E.A.; Wheeler, M.C.; Frederick, B.G.; et al. Fast Pyrolysis of Pine Sawdust in a Fluidized-Bed Reactor. Energy Fuels 2010, 24, 2642-2651. [CrossRef]

17. Xie, Q.; Kong, S.; Liu, Y.; Zeng, H. Syngas production by two-stage method of biomass catalytic pyrolysis and gasification. Bioresour. Technol. 2012, 110, 603-609. [CrossRef] [PubMed]

18. Qu, B.Y.; Zhang, Y.; Wang, T.; Li, A.; Wu, Z.; Ji, G. Dynamic Pyrolysis Characteristics, Kinetics and Products Analysis of Waste Tire Catalytic Pyrolysis with Ni/Fe-ZSM-5 Catalysts Using TG-IR-GC/MS. Catalysts 2021, 11, 1031. [CrossRef]

19. Galiwango, E.; Al-Marzuoqi, A.H.; Khaleel, A.A.; Abu-Omar, M.M. Catalytic Depolymerization of Date Palm Waste to Valuable C5-C12 Compounds. Catalysts 2021, 11, 371. [CrossRef]

20. Kim, J.H.; Jung, S.; Lin, K.Y.A.; Rinklebe, J.; Kwon, E.E. Comparative study on carbon dioxide-cofed catalytic pyrolysis of grass and woody biomass. Bioresour. Technol. 2021, 323. [CrossRef]

21. Santamaria, L.; Lopez, G.; Fernandez, E.; Cortazar, M.; Arregi, A.; Olazar, M.; Bilbao, J. Progress on Catalyst Development for the Steam Reforming of Biomass and Waste Plastics Pyrolysis Volatiles: A Review. Energy Fuels 2021, 35, 17051-17084. [CrossRef] [PubMed]

22. Gao, N.; Salisu, J.; Quan, C.; Williams, P. Modified nickel-based catalysts for improved steam reforming of biomass tar: A critical review. Renew. Sustain. Energ. Rev. 2021, 145, 111023. [CrossRef]

23. Aljeradat, R.A.; Aljbour, S.H.; Jarrah, N.A. Natural minerals as potential catalysts for the pyrolysis of date kernels: Effect of catalysts on products yield and bio-oil quality. Energy Sources A Recovery Util. Environ. Eff. 2021. [CrossRef]

24. Khan, S.R.; Zeeshan, M.; Ahmed, A.; Saeed, S. Comparison of synthetic and low-cost natural zeolite for bio-oil focused pyrolysis of raw and pretreated biomass. J. Clean. Prod. 2021, 313. [CrossRef]

25. Kawi, S.; Ashok, J.; Dewangan, N.; Pati, S.; Chen, J.M. Recent Advances in Catalyst Technology for Biomass Tar Model Reforming: Thermal, Plasma and Membrane Reactors. Waste Biomass Valorization 2022, 13, 1-30. [CrossRef]

26. Li, Q.; Ye, H.D.; Wang, Z.H.; Zhou, H.Y.; Wei, J.C. Characteristics and evolution of products under moderate and high temperature coal pyrolysis in drop tube furnace. J. Energy Inst. 2021, 96, 121-127. [CrossRef]

27. Xu, K.; Hu, S.; Zhang, L.P.; Li, H.J.; Chen, Y.F.; Xiong, Z.; Xu, J.; Jiang, L.; Wang, Y.; Su, S.; et al. Effect of temperature on Shenfu coal pyrolysis process related to its chemical structure transformation. Fuel Process. Technol. 2021, 213. [CrossRef]

28. Tangstad, M.; Beukes, J.P.; Steenkamp, J.; Ringdalen, E. 14-Coal-based reducing agents in ferroalloys and silicon production. In New Trends in Coal Conversion; Suárez-Ruiz, I., Diez, M.A., Rubiera, F., Eds.; Woodhead Publishing: Cambridge, UK, 2019; pp. 405-438. [CrossRef]

29. Martín, M.M. Chapter 5-Syngas. In Industrial Chemical Process Analysis and Design; Martín, M.M., Ed.; Elsevier: Boston, MA, USA, 2016; pp. 199-297. [CrossRef]

30. Santamaria, L.; Beirow, M.; Mangold, F.; Lopez, G.; Olazar, M.; Schmid, M.; Li, Z.; Scheffknecht, G. Influence of temperature on products from fluidized bed pyrolysis of wood and solid recovered fuel. Fuel 2021, 283, 118922. [CrossRef]

31. Lin, J.; Zhang, Q.; Xia, H.; Cheng, S. Effect of pyrolysis temperature on pyrolysis of pine saw dust and application of bio-char. Int J. Environ. Sci. Technol. 2021. [CrossRef]

32. Zhao, B.F.; Yang, H.J.; Zhang, H.M.; Zhong, C.Q.; Wang, J.W.; Zhu, D.; Guan, H.B.; Sun, L.Z.; Yang, S.X.; Chen, L.; et al. Study on hydrogen-rich gas production by biomass catalytic pyrolysis assisted with magnetic field. J. Anal. Appl. Pyrolysis 2021, 157. [CrossRef] 